\title{
DLBS1033, A Protein Extract from Lumbricus rubellus, Possesses Antithrombotic and Thrombolytic Activities
}

\author{
Jessica Trisina, ${ }^{1}$ Febrina Sunardi, ${ }^{1}$ Maggy T. Suhartono, ${ }^{1,2}$ and Raymond R. Tjandrawinata ${ }^{1}$ \\ ${ }^{1}$ Division of Protein Biochemistry and Molecular Pharmacology, Dexa Laboratories of Biomolecular Sciences, PT Dexa Medica, \\ Industri Selatan V Block PP no. 7, Kawasan Industri Jababeka II, Cikarang 17550, Indonesia \\ ${ }^{2}$ Department of Food Science and Technology, Bogor Agricultural University, Fateta Building Kampus IPB Darmaga, \\ Bogor 16680, Indonesia \\ Correspondence should be addressed to Raymond R. Tjandrawinata, raymond@dexa-medica.com
}

Received 9 November 2010; Revised 17 December 2010; Accepted 15 January 2011

Academic Editor: Michael Kalafatis

Copyright ( $) 2011$ Jessica Trisina et al. This is an open access article distributed under the Creative Commons Attribution License, which permits unrestricted use, distribution, and reproduction in any medium, provided the original work is properly cited.

The medicinal value of earthworm has been widely known since the history of Asian ancient medicine. This present study aims to determine the mechanism of action and effect of a standardized extract of Lumbricus rubellus named as DLBS1033. The fibrinogen degradation, antiplatelet aggregation, and ex vivo antithrombotic assay using human blood were performed to study antithrombotic activity. Fibrin plate and clot lysis assay were also done to examine thrombolytic properties. DLBS1033 was found to possess fibrinogenolytic activity on $\alpha$-, $\beta$-, and $\gamma$-chain of fibrinogen. It also induced antiplatelet aggregation and prolonged blood clotting time, which further confirmed its antithrombotic properties. In addition, thrombolytic properties of DLBS1033 were shown with its fast and long-acting fibrinolytic activity, as well as its effective blood clot lysis activities. In conclusion, DLBS1033 conferred antithrombotic and thrombolytic action which could be used as a safe and promising oral thrombolytic drug.

\section{Introduction}

For several years, earthworms have been widely used in Indonesia, China, Japan, and the Far East to treat various chronic diseases. Deep exploration has been made to reveal the use of earthworms as antimicrobial [1], antiinflammatory [2], and anticancer [3] agents.

In 1991, Mihara et al. found that the earthworm from Lumbricidae family could directly dissolve fibrin and activate plasminogen [4]. The active constituents of earthworm have been characterized and known to have fibrinolytic enzymes, a group of serine protease enzymes. Earthworm fibrinolytic enzymes (EFEs) are composed of several isozymes which can be transported into blood through intestinal epithelium [5-7]. It confers fibrinolytic and fibrinogenolytic properties, lowers blood viscosity, markedly reduces platelet aggregation, and promotes thrombus degradation in blood [810]. Due to those properties, earthworm fibrinolytic enzyme has been extensively studied as an oral thrombolytic drug $[10,11]$.
The most common sources of earthworm fibrinolytic enzymes are Lumbricus rubellus, Eisenia foetida, and Pheretima sp. Each earthworm has different isozyme constituents depending on the species and living environment [12] that may lead to differences in their activities. Recently, research progress has been made using earthworm as one of its natural resources in developing medicines to treat thrombosisrelated diseases. It is one of the most widely occurring diseases in modern life, which often cause disability and death. This present study was intended to explore the characterization, activity, and mechanism of actions of DLBS1033, earthworm extract prepared from Lumbricus rubellus originated from Indonesia, with regards to its antithrombotic and thrombolytic activities as a promising therapeutic agent for thrombosis-associated diseases.

\section{Materials and Methods}

DLBS1033 was prepared in Dexa Laboratories of Biomolecular Sciences (Cikarang, Indonesia). Lumbricus rubellus 
obtained from Pangalengan, West Java, Indonesia, was extracted using purified water, followed by continuous centrifugation (Westfalia, Germany) at room temperature. Supernatant was then concentrated using rotavapor (Büchi, Switzerland) and made into powdery form using fluid bed dryer (Niro, Germany). DLBS1033 was then sterilized using irradiation with gamma ray at total dose of 10$12 \mathrm{kGy}$ to prevent the bacterial protease contaminating it. Bovine serum albumin (BSA) fraction $\mathrm{V}$ and thrombin for biochemistry were purchased from Merck (Darmstadt, Germany). Human fibrinogen fraction I was obtained from Sigma Aldrich (St. Louis, USA). LMW marker protein was acquired from Amersham, Bioscience. Other reagents used were of analytical grade.

\subsection{Characterization of DLBS1033}

2.1.1. Protein Content and Protease Activity of DLBS1033. Protein content of DLBS1033 was measured using modified Bradford Assay. $100 \mu \mathrm{L}$ of $50 \mathrm{mg} / \mathrm{mL}$ DLBS1033 in $20 \mathrm{mM}$ potassium phosphate buffer were mixed with $2 \mathrm{~mL}$ of Bradford reagent. Mixture was incubated at room temperature for $5 \mathrm{~min}$, and its absorbance was measured at $595 \mathrm{~nm}$.

Protease assay was done to measure the protease activity of DLBS1033 [13]. $250 \mu \mathrm{L}$ DLBS1033 (50 mg/mL) in $20 \mathrm{mM}$ potassium phosphate buffer and casein solution were mixed and incubated at $37^{\circ} \mathrm{C}$ for $10 \mathrm{~min}$. Reaction was stopped using trichloroacetic acid solution. The soluble peptides were then separated from the mixtures using centrifugation. To develop color, supernatant and Folin's reagent were mixed under basic conditions by the addition of $\mathrm{Na}_{2} \mathrm{CO}_{3}$ solution. The mixture was then measured for its absorbance at $660 \mathrm{~nm}$.

The specific activity was $1180 \mathrm{U} / \mathrm{mg}$ protein. One unit was defined as the amount in micromoles of tyrosine equivalents released from casein per minute at $\mathrm{pH} 7.5,37^{\circ} \mathrm{C}$.

The stability of DLBS1033 was also analyzed for its stability at different $\mathrm{pH}$ and temperature. The effect of $\mathrm{pH}$ on the activity of DLBS1033 was examined under the range of $\mathrm{pH} 2$ to 14 . DLBS1033 began to exhibit its protease activity at $\mathrm{pH} 4$ which gradually increased up to $\mathrm{pH} 12$ (Figure 1). The activity then dropped drastically at $\mathrm{pH}$ 13. Between $\mathrm{pH}$ 4 and 12, the optimal activities and stability of DLBS1033 were maintained.

Activity and stability of DLBS1033 were also estimated based on its activity to degrade casein. The extract was incubated in various temperatures ranging from $25^{\circ} \mathrm{C}-80^{\circ} \mathrm{C}$ for 5 hours. The result shows that DLBS1033 gave different response in terms of its protease activity when incubated at different temperatures (Figure 2). The activity of DLBS1033 was lowest at about $0.5-2 \mathrm{U} / \mathrm{mg}$ when it was incubated at $80^{\circ} \mathrm{C}$. The optimum temperature of DLBS1033 appeared to be $50^{\circ} \mathrm{C}$, where its activity was still maintained until 5-hour incubation time.

2.1.2. DLBS1033 Protein Profile. Protein pattern of DLBS1033 was assayed using SDS PAGE. 12\% polyacrylamide gel, $15 \mu \mathrm{L}$ DLBS1033 as sample and LMW protein as ladder were used.

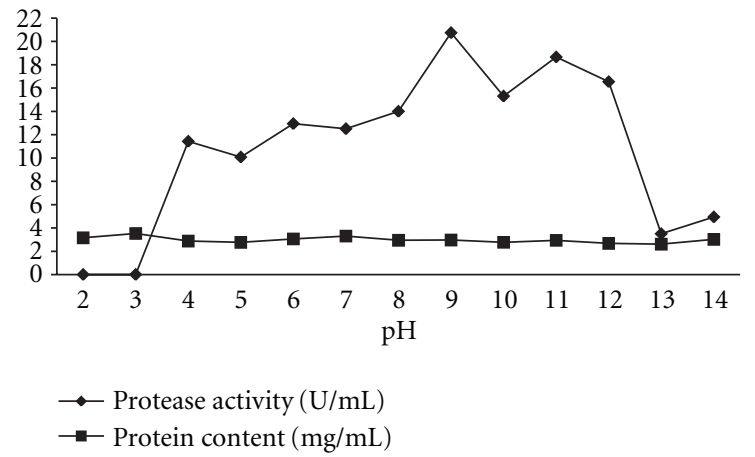

FIgURE 1: Stability of DLBS1033 in the range of pH. DLBS1033 was examined in $\mathrm{pH}$ range of 2-14.

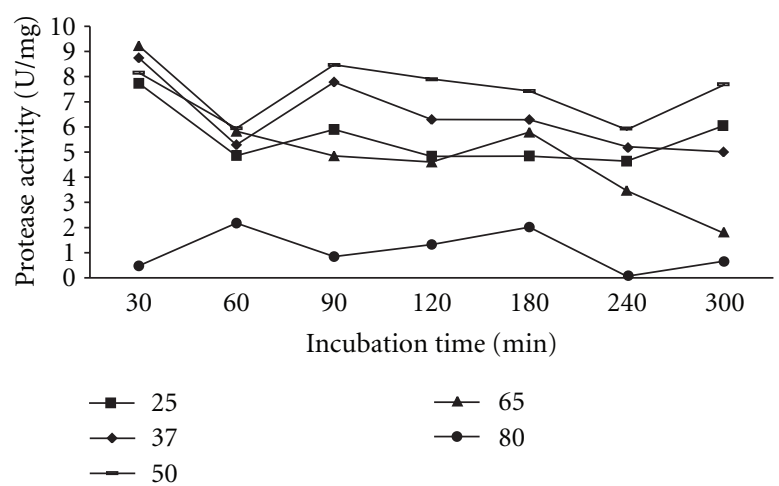

FIGURE 2: Stability of DLBS1033 in the range of temperature. DLBS1033 was examined in temperature range of $25^{\circ} \mathrm{C}-80^{\circ} \mathrm{C}$ for 5 hours.

The following SDS PAGE shows that DLBS1033 has a specific group of proteins as its constituents. As can be seen in Figure 3, the earthworm extract possesses 8 major proteins with molecular weight below $100 \mathrm{kDa}$. This specific protein pattern gives DLBS1033 its unique characteristic, named as LLP (Lumbricus low molecular-weight proteins).

The specific proteolytic activity of DLBS1033 LLP was confirmed with fibrinogen zymography. Zymography is based on a sodium dodecyl sulfate polyacrylamide gel impregnated with protein substrate which is later degraded by the proteases during incubation [14]. $50 \mathrm{mg} / \mathrm{mL}$ DLBS1033 in $50 \mathrm{mM}$ phosphate buffer and native polyacrylamide gel 12\% containing 1\% fibrinogen were used for the experiment. After electrophoresis, gel was renatured using 2.5\% tween-20 solution for $30 \mathrm{~min}$ under gentle agitation and then rinsed in purified water. The gel was then incubated with $50 \mathrm{mM}$ phosphate buffer in $37^{\circ} \mathrm{C}$ for $3 \mathrm{~h}$. After incubation, it was stained in coomassie blue staining solution and destained in solution containing methanol:acetic acid: water $(1: 1: 8, \mathrm{v}: \mathrm{v}: \mathrm{v})$. The presence of enzymes with fibrinogenolytic activity was identified as clear bands on blue background gel. The result (Figure 4) showed several clear bands on the zymogram gel indicating the specific fibrinogenolytic activity of DLBS1033 LLP. 


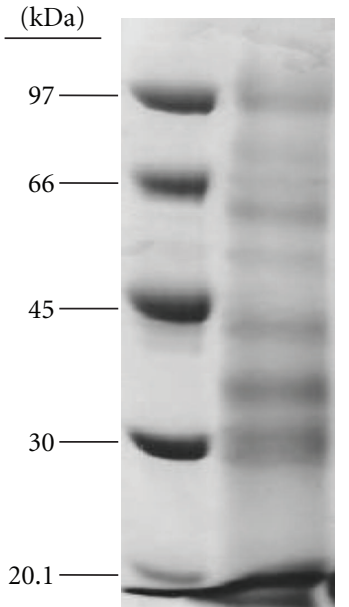

Figure 3: Lumbricus low-molecular-weight protein profile of DLBS1033. The eathworm extract has 8 major proteins with molecular weight below $100 \mathrm{kDa}$.

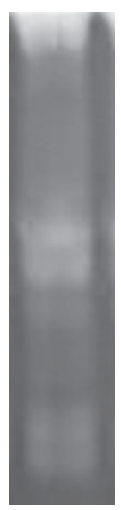

FIGURE 4: Fibrinogen zymogram of DLBS1033. LLP fractions which contribute to fibrinogenolytic activity were identified as clear bands.

Since LLP was a strong fibrinolytic enzyme and impeded the formation of fibrin, light scattering at $480 \mathrm{~nm}$ was used to assay this enzyme's activity using chromozym $\mathrm{TH}$ as substrate. Chromozym TH (Tos-Gly-Pro-Arg-4-nitranilide acetate) is usually used as substrate for the determination of serine protease in aqueous solution. Initially, $2.8 \mathrm{~mL}$ Tris buffer and $0.3 \mathrm{~mL}$ of $1.9 \mathrm{mM}$ Chromozym TH were mixed in a plastic cuvette and the temperature in the cuvette was maintained at $25^{\circ} \mathrm{C}$. The reaction was then started by adding $0.1 \mathrm{~mL}$ of $0.175 \mathrm{mg} / \mathrm{mL}$ DLBS1033. After that, the mixture was then observed for its change in absorbance and $\Delta \mathrm{A} / \mathrm{min}$ was calculated from the linear range using the formula: $\mathrm{U} / \mathrm{mL}$ sample solution: $3.077 \times \Delta \mathrm{A} / \mathrm{min}$. Figure 5(a) showed that the absorbance increased gradually until it reached plateau after 12 minutes. Moreover, the linear section of changes in absorbance per one minute (Figure 5(b)) was used to estimate the activity of LLP. The activity of LLP on Chromozym TH was obtained to be $2.549 \mathrm{U} / \mathrm{mg}$.

\subsection{Antithrombotic Properties}

2.2.1. Fibrinogen Degradation Assay. 12\% SDS-PAGE was used for fibrinogen degradation assay. $500 \mu \mathrm{L}$ fibrinogen $(5 \mu \mathrm{g} / \mu \mathrm{L}$ final concentration) and $500 \mu \mathrm{L}$ DLBS1033 $(0.8 \mu \mathrm{g} / \mu \mathrm{L}$ protein concentration) were mixed in $20 \mathrm{mM}$ phosphate buffer and incubated at $37^{\circ} \mathrm{C}$. Aliquots were taken at different time intervals for SDS-PAGE analysis. Gel was stained in coomassie blue solution. Low-molecular-weight protein marker was used as standard.

2.2.2. Antiplatelet Aggregation Assay. The human blood samples were collected from healthy adult volunteers. Informed consents were obtained before blood collection. The collection was monitored and approved by the local IRB from Dexa Medica Group. The blood sample was put into 3.2\% sodium citrate solution in a 9:1 (v/v) ratio. Platelets were isolated by differential centrifugation of blood ( $20 \mathrm{~min}$ at 100 $\times g$ ) to obtain the platelet-rich plasma (PRP). The samples were centrifuged again at $1600 \times \mathrm{g}$ for $10 \mathrm{~min}$ and plateletpoor plasma (PPP) was recovered from the supernatant as a control. PRP was preincubated with DLBS1033 (5$75 \mathrm{mg} / \mathrm{mL}$ ) for $60 \mathrm{~min}$ at $37^{\circ} \mathrm{C}$. Platelet aggregation was measured at $37^{\circ} \mathrm{C}$ by light transmission using AggRam platelet aggregation system (Helena Laboratories, PACK-4, Beaumont, TX) with stirring rate of $600 \mathrm{rpm}$. The baseline was adjusted with PPP. A total of $250 \mu \mathrm{L}$ of sample was drawn using a pipette into an aggregation cuvette and incubated for $3 \mathrm{~min}$. The samples were then activated with $10 \mu \mathrm{M}$ ADP and thrombin and platelet aggregation was recorded for $6 \mathrm{~min}$. EDTA and Cilostazol were used as positive control.

2.2.3. Ex Vivo Antithrombosis Assay. Blood samples were taken from healthy male volunteers after giving informed consent. The DLBS1033 in various concentrations $(50,100$, and $200 \mathrm{mg} / \mathrm{mL}$ ) was used as sample and $20 \mathrm{mM}$ potassium phosphate as blank. $250 \mu \mathrm{L}$ blank and $250 \mu \mathrm{L}$ sample of different concentrations were mixed with $4 \mu \mathrm{L}$ thrombin (0.92 IU) and $250 \mu \mathrm{L}$ fresh blood on a ceramic tile. Mixture was incubated at $37^{\circ} \mathrm{C}$ and coagulation of blood was observed after $1 \mathrm{~h}$.

\subsection{Thrombolytic Properties}

2.3.1. Fibrin Plate Assay. The fibrinolytic activity of DLBS1033 was measured using fibrin plate assay [15] with slight modification on the amount of sample. $1 \%$ fibrinogen solution (Sigma) was prepared in 1x Phosphate buffer saline (1x PBS). $10 \mathrm{~mL}$ of the solution was distributed slowly into each sterile petri dish $(13 \mathrm{~cm}) .12 .5 \mu \mathrm{L}$ of $100 \mathrm{U} / \mu \mathrm{L}$ thrombin solution in 1x PBS was added into the plate and solidified for $30 \mathrm{~min}$ at room temperature. Membrane discs were put on the fibrin plate surface. DLBS1033 $(50 \mathrm{mg} / \mathrm{mL})$ was prepared in $20 \mathrm{mM}$ phosphate buffer and $75 \mu \mathrm{L}$ aliquot was used as sample. Sample and standard solutions were put separately on membrane discs in the fibrin plate. The plates were then incubated at $37^{\circ} \mathrm{C}$ and observed at $1,2,3,4,6,8,10$, and $12 \mathrm{~h}$. The mean diameter of the hydrolyzed clear zone was 


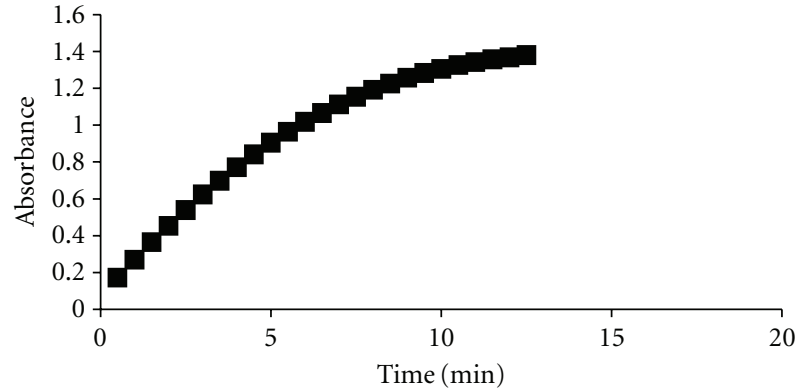

(a)

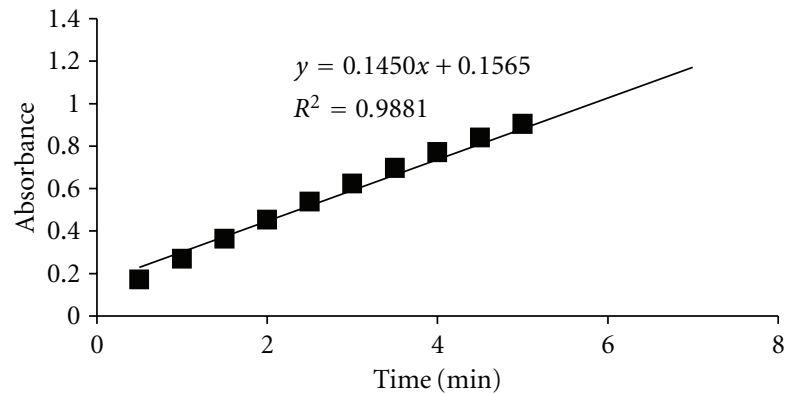

(b)

FIgURE 5: Activity of DLBS1033 on chromozym substrate. (a) Change in the absorbance at $405 \mathrm{~nm}$ during assay of DLBS1033 with chromozyme. (b) Linear section of changes in absorbance per one minute.

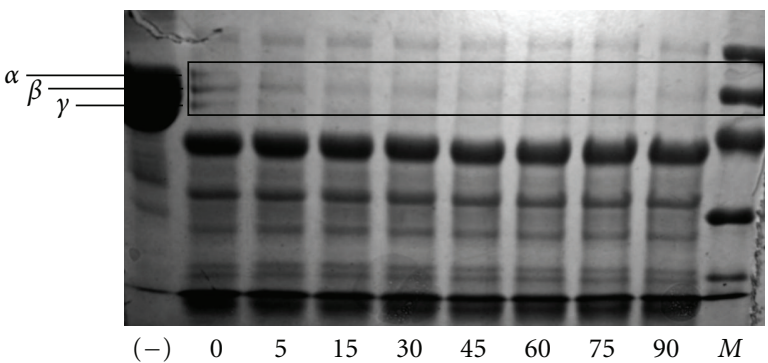

FIGURE 6: Fibrinogen degradation by DLBS1033. Lane 1: fibrinogen. Lanes 2-8 representing mixtures aliquot were taken at $0,5,15$, $30,45,60$, and $90 \mathrm{~min}$, respectively.

measured and volume of lysis caused by DLBS1033 was then calculated.

2.3.2. Clot Lysis Assay. Clot lysis assay was carried out according to Prasad et al. [16]. Venous blood was drawn from healthy volunteers after giving informed consent $(n=$ 3). $500 \mu \mathrm{L}$ venous blood was put into pre-weighed sterile microcentrifuge tube and incubated at $37^{\circ} \mathrm{C}$ for $60 \mathrm{~min}$. After that, serum was removed from the blood clot. Phosphate buffer $20 \mathrm{mM}$ as blank and $100 \mu \mathrm{L}$ of $50 \mathrm{mg} / \mathrm{mL}$ DLBS1033 in phosphate buffer $20 \mathrm{mM}$ were added separately to the clot and incubated at $37^{\circ} \mathrm{C}$ for $120 \mathrm{~min}$. Fluid was removed from the remaining clots and the tubes were weighed. Thrombolytic activity was calculated by comparing the initial weight of blood clot to that of lysed blood clot.

\section{Results}

\subsection{Antithrombotic Properties}

3.1.1. Fibrinogen Degradation Assay. The fibrinogen hydrolysis pattern of DLBS1033 was observed on $\alpha$-, $\beta$-, and $\gamma$-chain of fibrinogen. The fibrinogenolytic activity could be detected within $5 \mathrm{~min}$ (Figure 6). $\alpha$ - and $\gamma$-chain of fibrinogen had been completely degraded after $30 \mathrm{~min}$, except for the slight $\beta$-chain that still remained until 90-min incubation. The fact that the fibrinogen chains were fully cleaved in a short time indicated that DLBS1033 possessed stronger fibrinogenolytic activity on $\alpha$-and $\gamma$-chain than on $\beta$-chain.

3.1.2. Antiplatelet Aggregation Assay. In order to observe the aggregation activity, thrombin and ADP were used in this experiment as standard platelet aggregation activator. Thrombin-induced platelet aggregation was reduced in a dose-dependent manner when treated with DLBS1033. DLBS1033 could totally inhibit the aggregation when its concentration was more than $60 \mathrm{mg} / \mathrm{mL}$ (Figure $7(\mathrm{a})$ ). Comparing to EDTA, when mixed with thrombin, it could significantly reduce the platelet aggregation by up to $95 \%$. Similar manner was observed in ADP-induced aggregation that had been treated with DLBS1033 (Figure 7(b)). DLBS1033 could completely reduce platelet aggregation at dose above $75 \mathrm{mg} / \mathrm{mL}$. As a comparison, cilostazol, when mixed with ADP, could only reduce platelet aggregation by $15 \%$, which was relatively insignificant.

In both cases, inhibition of aggregation was optimum at a dose between 40 and $75 \mathrm{mg} / \mathrm{mL}$ where DLBS1033 could reduce more than $50 \%$ of the standard aggregation induced by thrombin and ADP. This data suggests that DLBS1033 is a strong antiplatelet aggregation agent.

3.1.3. Ex Vivo Antithrombotic Assay. DLBS1033 showed antithrombotic inhibition activity by prolonging the blood clotting time (Figure 8). In the first 5 minutes, blood clot had already been formed in the mixture with potassium phosphate buffer as a blank, while no clot occurred when treated with DLBS1033 in various concentrations. After 5 minutes, although blood clot had begun to form, including in the sample receiving the highest concentration treatment, the clot formation, took longer time with reduced clot consistency. The result indicates that DLBS1033, in a dosedependent manner can prolong the clotting time and also, reduce the consistency of clot as compared to that of the blank.

\subsection{Thrombolytic Properties}

3.2.1. Fibrin Plate Assay. As evident in the formation of lysis zone in fibrin plate, DLBS1033 had degraded fibrin into 


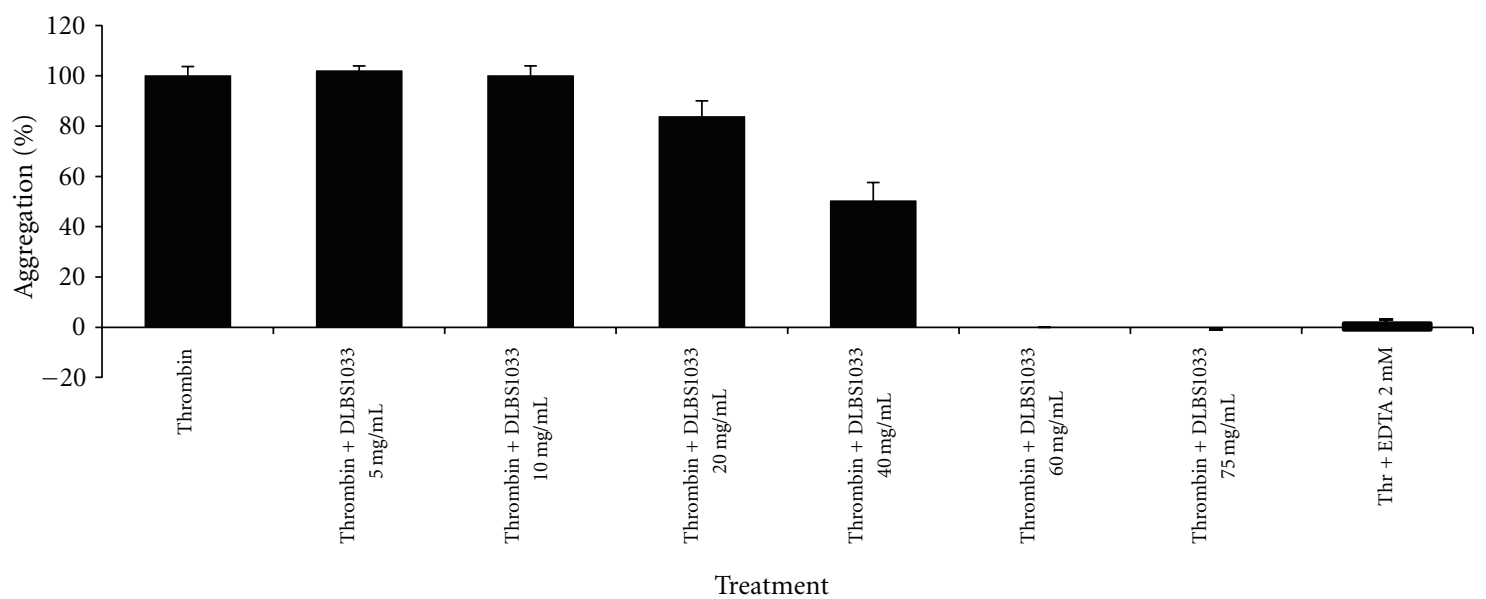

(a)

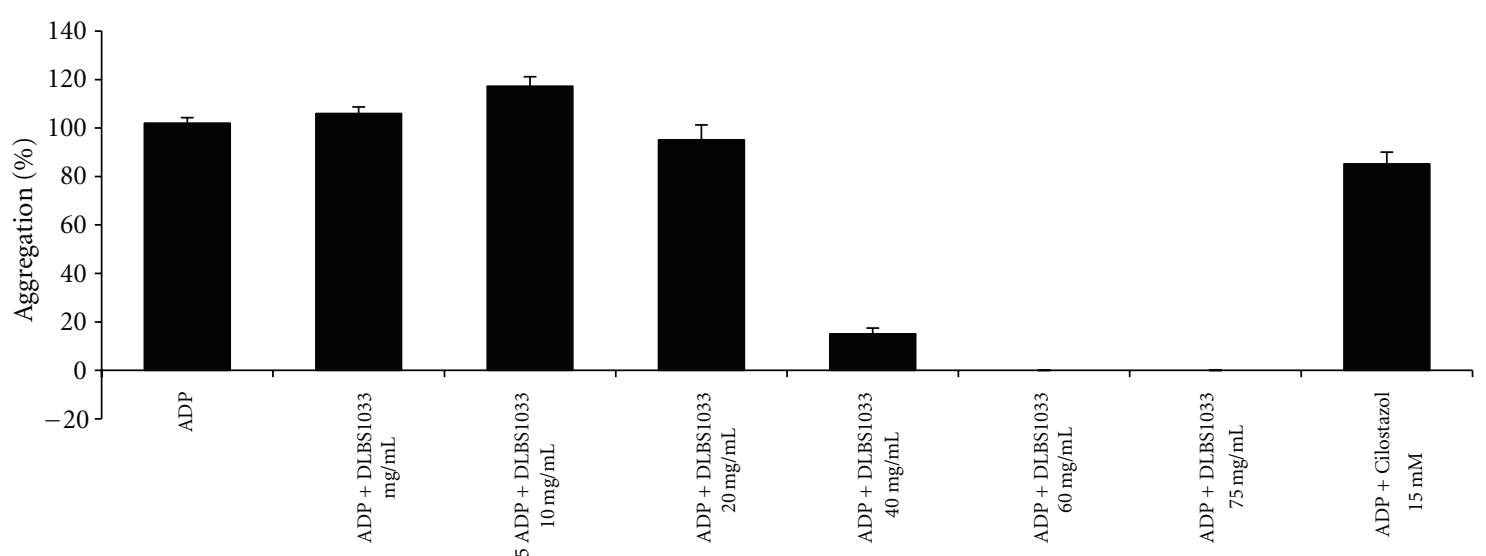

Treatment

(b)

FIGURE 7: Inhibition of platelet aggregation by DLBS1033. Platelet aggregation induced by thrombin (a) and ADP (b) was downregulated by the administration of DLBS1033. EDTA and cilostazol were used as the positive control.

\begin{tabular}{|c|c|c|c|c|c|}
\hline \multirow[b]{2}{*}{$\begin{array}{l}\text { Time } \\
(\mathrm{min})\end{array}$} & \multirow[b]{2}{*}{ Clot formation } & \multicolumn{4}{|c|}{ DLBS1033 } \\
\hline & & $\begin{array}{c}0 \\
\mathrm{mg} / \mathrm{mL}\end{array}$ & $\begin{array}{c}50 \\
\mathrm{mg} / \mathrm{mL}\end{array}$ & $\begin{array}{c}100 \\
\mathrm{mg} / \mathrm{mL}\end{array}$ & $\begin{array}{c}200 \\
\mathrm{mg} / \mathrm{mL}\end{array}$ \\
\hline 0 & & - & - & - & - \\
\hline 5 & & +++ & ++ & + & - \\
\hline 15 & & +++ & ++ & + & + \\
\hline 30 & & +++ & ++ & ++ & + \\
\hline 60 & & +++ & ++ & ++ & + \\
\hline 120 & & +++ & ++ & ++ & + \\
\hline
\end{tabular}

Figure 8: Ex vivo antithrombotic effect of DLBS1033. The clot formation was inhibited after the administration of DLBS1033. +++ : fully clotted; high clotting consistency; ++: partially clotted, medium clotting consistency; +: slightly clotted, low clotting consistency; -: no clot occurred.

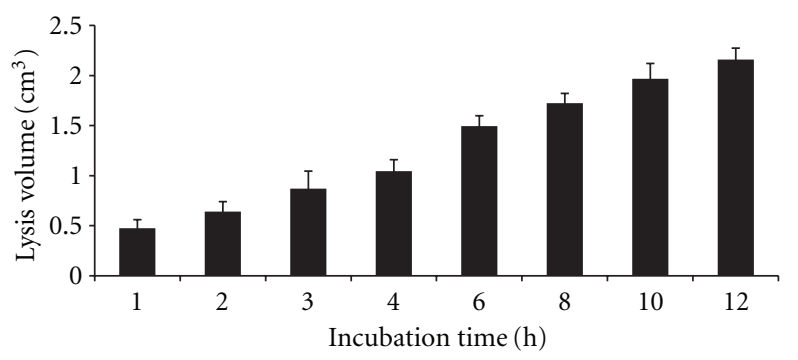

Figure 9: Volume of fibrin lysed by DLBS1033 was calculated at incubation time intervals.

soluble peptides, indicating its fibrinolytic activity. The lysis volume for each time interval was then calculated. Figure 9 shows that lysis volume could be quantified from the first hour of incubation period during which the volume kept increasing until the 12th hour. This indicates that DLBS1033 possesses a fast and long-acting fibrinolytic activity. 


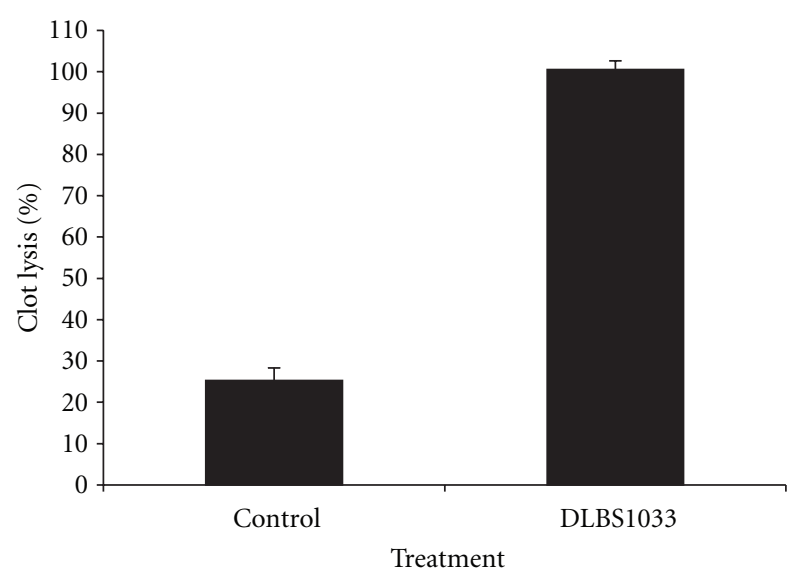

FIGURe 10: Lysis of blood clot by DLBS1033. Clot lysis was measured and compared between control and DLBS1033.

3.2.2. Clot Lysis Assay. The effectiveness of DLBS1033 in dissolving fibrin in blood clot was then assayed using clot lysis assay. The effect of DLBS1033 in clot lysis was obvious in Figure 10. The amount of the blood lysed when treated with DLBS1033 was 4-fold higher than that of the blank.

\section{Discussion}

The present study was performed to investigate the activities of DLBS1033 as antithrombotic and thrombolytic agent. Antithrombotic properties of DLBS1033 were first assayed on fibrinogen which is one of the major components in the coagulation pathway. Fibrinogen hydrolysis pattern conferred by DLBS1033 was studied. During blood coagulation, thrombin converts fibrinogen to fibrin monomers, which associate into staggered, overlapping, 2-stranded fibrils. These 2-stranded fibrils laterally associate to form fibrin bundles [17]. The three polypeptide chains of fibrinogen $(\alpha-66 \mathrm{kd}, \beta-54 \mathrm{kd}$, and $\gamma$ chain-48 kd) [18] were degraded in different manners during incubation with DLBS1033 (Figure 6). The $\alpha$ - and $\gamma$-chain were completely degraded first, whereas the $\beta$-chain was slightly more resistant toward degradation.

The degradation activity of DLBS1033 on the fibrinogen chains can decrease blood viscosity level, since blood viscosity is correlated with fibrinogen level in the blood [19]. The fibrinogen $\alpha$ - chain is known to play an important role in thrombin-induced fibrin formation [20]. Moreover, $y$ chain of fibrinogen reveals the main sites for interaction with membrane receptor in the platelet [18], where the aggregation process is mediated by binding of the fibrinogen to a platelet cell surface receptor, glycoprotein IIb-IIIa [21]. Thus, the fast and complete degradation of $\alpha$ and $\gamma$-chain may play a significant role in performing antithrombotic process. Our data showed that DLBS1033 degraded $\alpha$ and $\gamma$ chain rapidly, indicating that DLBS1033 possesses effective antithrombotic activity.

DLBS1033 was shown to exhibit antiplatelet aggregation activity which was induced by ADP and thrombin (Figures $7(\mathrm{a})$ and $7(\mathrm{~b}))$. Platelets play a crucial role in thrombosis, especially in arterial thrombosis and their pathologies [22]. The pharmacological mechanism of aggregation inhibition was supposed to be effectively performed by increasing the cAMP level and inhibiting Ca transport as have been reported previously [10].

The ex vivo coagulation model was studied using human blood induced by thrombin which formed blood clots within 2-hour observation. DLBS1033 was shown to prolong the thrombus formation time (Figure 8). Thrombus formation is influenced by the presence of thrombin which promotes coagulation pathway activation [23]. The formation of blood clot still occurred even with administration of high concentration of DLBS1033, but with prolonged clotting time. Furthermore, in this experiment, it was noticed that the consistency of blood clot was also significantly reduced in a dose-dependent manner. The reduced clot consistency might have occurred due to the effect of digested $\gamma$-chain of fibrinogen which was important for stabilization of fibrin formation [18] or due to the fibrinolytic activity of the remaining DLBS1033 [19].

To further investigate the fibrinolytic activity of DLBS1033, the fibrin plate assay was developed. DLBS1033 is a relatively fast and long-acting fibrinolysis agent, where the lysis zone in the fibrin plate has already formed up to quantifiable amount within 1-hour incubation, and its fibrinolysis activity still lasted up to 12 hours (Figure 9). This finding was similar to previous results that earthworm possessed direct activity toward fibrin $[4,9]$.

The activity of DLBS1033 in the presence of thrombus was then assessed by conducting clot lysis assay using human blood clot, where the main protein component is fibrin. Weight of the clot before and after lysis was considered as appropriate determinant of calculating clot lysis percentage [16]. Other methods such as calculation based on sample turbidity could not accurately determine the clot lysed by DLBS1033 due to color of extract which is yellow to brown and the low-molecular weight protein, as well as other nonprotein components present in this extract. The result showed a remarkable degradation of blood clot by DLBS1033 compared to the control added only with phosphate buffer (Figure 10). This indicates that the degradation effect of DLBS1033 towards human blood clot is mainly due to its fibrinolytic activity. The activity was shown to be strong enough to penetrate into complex environment of thrombus and resulted in the fibrin degradation. Therefore, DLBS1033 may serve as a promising thrombolytic agent.

This present data indicates that DLBS1033, a unique agent generated from Lumbricus rubellus earthworm possesses antithrombotic and thrombolytic activity. Antithrombotic activity is shown by its fibrinogenolytic and antiplatelet aggregation activities, whereas its thrombolytic activity is exhibited by fibrinolytic and blood clot lysis activities. In addition, this agent had been proven safe without causing any clinically severe adverse events during administration. Therefore, DLBS1033 is suggested as a promising agent for treating thrombus-related disease. Further studies are necessary to investigate the characteristic activity of earthworm 
extract in facilitating blood circulation and also in other diseases.

\section{Conflict of Interests}

The authors declare no conflict of interests.

\section{Acknowledgment}

The authors thank Laurentia Stephani and Puji Rahayu for their contribution in this research; and Audrey Clarissa and Venni Carolina for careful reading of the manuscript.

\section{References}

[1] M. Popović, M. Grdiša, and T. M. Hrženjak, "Glycolipoprotein G-90 obtained from the earthworm Eisenia foetida exerts antibacterial activity," Veterinarski Arhiv, vol. 75, no. 2, pp. 119-128, 2005.

[2] M. Balamurugan, K. Parthasarathi, E. L. Cooper, and L. S. Ranganathan, "Anti-inflammatory and anti-pyretic activities of earthworm extract-Lampito mauritii (Kinberg)," Journal of Ethnopharmacology, vol. 121, no. 2, pp. 330-332, 2009.

[3] H. Chen, S. Takahashi, M. Imamura et al., "Earthworm fibrinolytic enzyme: anti-tumor activity on human hepatoma cells in vitro and in vivo," Chinese Medical Journal, vol. 120, no. 10, pp. 898-904, 2007.

[4] H. Mihara, H. Sumi, T. Yoneta et al., "A novel fibrinolytic enzyme extracted from the earthworm, Lumbricus rubellus," Japanese Journal of Physiology, vol. 41, no. 3, pp. 461-472, 1991.

[5] Q. Fan, C. Wu, L. Li et al., "Some features of intestinal absorption of intact fibrinolytic enzyme III-1 from Lumbricus rubellus," Biochimica et Biophysica Acta, vol. 1526, no. 3, pp. 286-292, 2001.

[6] X. M. Yan, C. H. Kim, C. K. Lee, J. S. Shin, I. H. Cho, and U. D. Sohn, "Intestinal absorption of fibrinolytic and proteolytic lumbrokinase extracted from earthworm, Eisenia andrei," Korean Journal of Physiology and Pharmacology, vol. 14, no. 2, pp. 71-75, 2010.

[7] Q. Yu, P. Li, and Q. Yang, "Improving the absorption of earthworm fibrinolytic enzymes with mucosal enhancers," Pharmaceutical Biology, vol. 48, no. 7, pp. 816-821, 2010.

[8] N. Nakajima, H. Mihara, and H. Sumi, "Characterization of potent fibrinolytic enzymes in earthworm, Lumbricus rubellus," Bioscience, Biotechnology and Biochemistry, vol. 57, no. 10, pp. 1726-1730, 1993.

[9] I. H. Cho, E. S. Choi, H. G. Lim, and H. H. Lee, "Purification and characterization of six fibrinolytic serine-proteases from earthworm Lumbricus rubellus," Journal of Biochemistry and Molecular Biology, vol. 37, no. 2, pp. 199-205, 2004.

[10] H. Ji, L. Wang, H. Bi et al., "Mechanisms of lumbrokinase in protection of cerebral ischemia," European Journal of Pharmacology, vol. 590, no. 1-3, pp. 281-289, 2008.

[11] L. Jin, H. Jin, G. Zhang, and G. Xu, "Changes in coagulation and tissue plasminogen activator after the treatment of cerebral infarction with lumbrokinase," Clinical Hemorheology and Microcirculation, vol. 23, no. 2-4, pp. 213-218, 2000.

[12] P. Rong, Z. J. Zhang, and R. Q. He, "Earthworm protease," Applied and Environmental Soil Science, vol. 2010, Article ID 294258, 13 pages, 2010.
[13] H. U. Bergmeyer and M. Grass, Methods of Enzymatic Analysis, Academic Press, New York, NY, USA, 1983.

[14] T. M. Leber and F. R. Balkwill, “Zymography: a single-step staining method for quantitation of proteolytic activity on substrate gels," Analytical Biochemistry, vol. 249, no. 1, pp. 2428, 1997.

[15] T. Astrup and S. Müllertz, "The fibrin plate method for estimating fibrinolytic activity," Archives of Biochemistry and Biophysics, vol. 40, no. 2, pp. 346-351, 1952.

[16] S. Prasad, R. S. Kashyap, J. Y. Deopujari, H. J. Purohit, G. M. Taori, and H. F. Daginawala, "Development of an in vitro model to study clot lysis activity of thrombolytic drugs," Thrombosis Journal, vol. 4, article no. 14, 2006.

[17] B. Blombäck, "Fibrinogen structure, activation, polymerization and fibrin gel structure," Thrombosis Research, vol. 75, no. 3, pp. 327-328, 1994.

[18] J. Hawiger, S. Timmons, and M. Kloczewiak, " $\gamma$ and $\alpha$ chains of human fibrinogen possess sites reactive with human platelet receptors," Proceedings of the National Academy of Sciences of the United States of America, vol. 79, no. 6, pp. 2068-2071, 1982.

[19] T. Matsuda and M. Murakami, "Relationship between fibrinogen and blood viscosity," Thrombosis Research, vol. 8, supplement 2, pp. 25-33, 1976.

[20] J. Zhao, R. Pan, J. He, Y. Liu, D. F. Li, and R. Q. He, "Eisenia fetida protease-III-1 functions in both fibrinolysis and fibrogenesis," Journal of Biomedicine and Biotechnology, vol. 2007, Article ID 97654, 10 pages, 2007.

[21] D. H. Farrell, P. Thiagarajan, D. W. Chung, and E. W. Davie, "Role of fibrinogen $\alpha$ and $\gamma$ chain sites in platelet aggregation," Proceedings of the National Academy of Sciences of the United States of America, vol. 89, no. 22, pp. 10729-10732, 1992.

[22] J. E. Freedman, "Molecular regulation of platelet-dependent thrombosis," Circulation, vol. 112, no. 17, pp. 2725-2734, 2005.

[23] B. J. Meyer, J. J. Badimon, J. H. Chesebro, J. T. Fallon, V. Fuster, and L. Badimon, "Dissolution of mural thrombus by specific thrombin inhibition with $\mathrm{r}$ - hirudin: comparison with heparin and aspirin," Circulation, vol. 97, no. 7, pp. 681-685, 1998. 

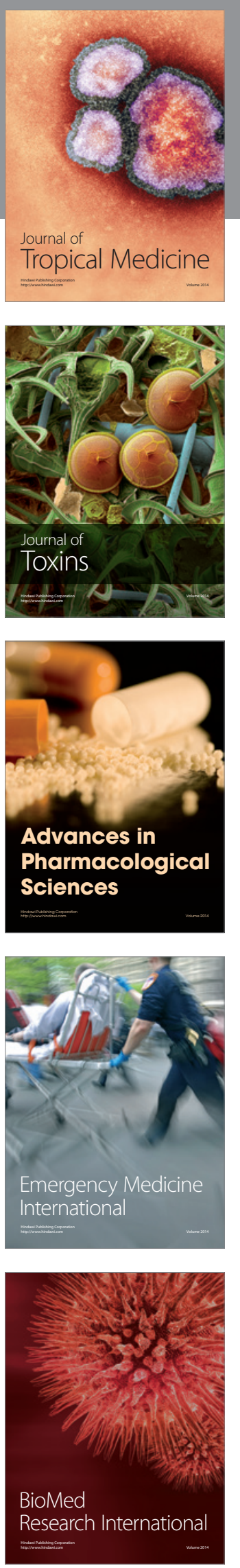
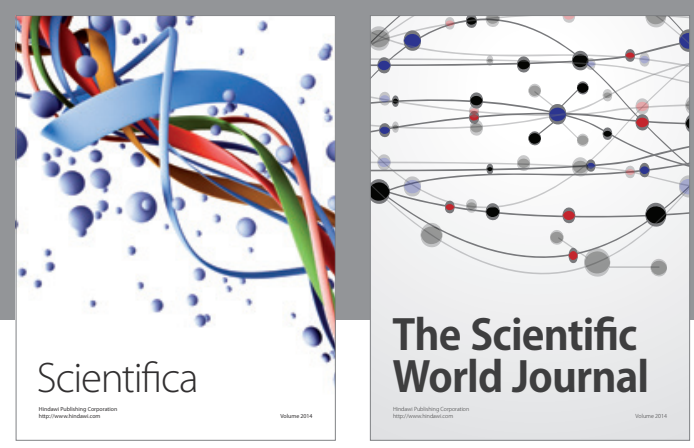

The Scientific World Journal
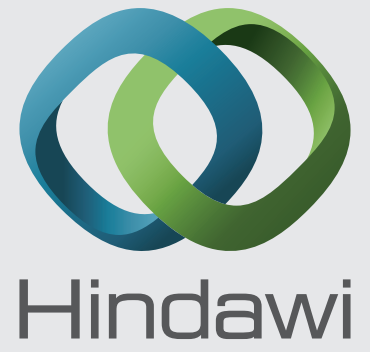

Submit your manuscripts at

http://www.hindawi.com
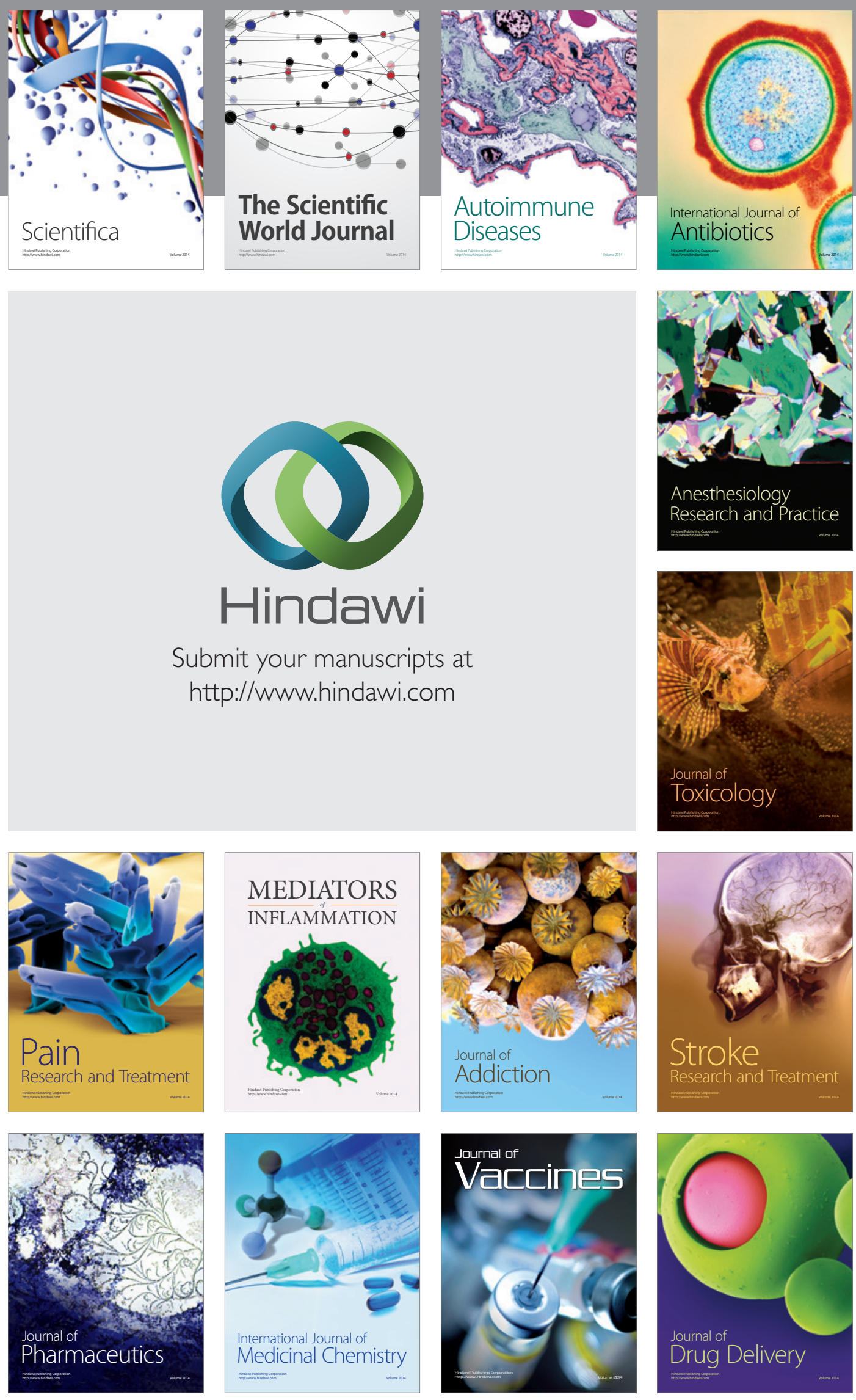